\title{
ELEKTRONISKĀ SAZIN̦A KĀ RAKSTVEIDA PIERĀDĪJUMS CIVILLIETĀ
}

\section{ELECTRONICALLY STORED INFORMATION (ESI) AS A WRITTEN EVIDENCE IN CIVIL MATTERS}

\section{Daina Ose, Dr. iur.}

Latvijas Universitātes Juridiskās fakultātes

Civiltiesisko zinātṇu katedras docente

\section{Summary}

In settlement of a civil dispute, an essential role pertains to electronic evidence. The wide variety of communication technology and its use in everyday life call for assessing the sufficiency of regulatory framework currently in use. Communication in its electronic form is not only a legally presented written acknowledgement, which is electronically signed, but it also includes audio and video recordings. Currently it is not necessary to define a special regulation in Latvian Civil Procedure Law in relation to the evaluation of the evidence expressed in electronic form, however, it is necessary to establish a unified court practice, which would lay a foundation for a related regulation in Civil Procedure Law, thus strengthening various ways of obtaining, presentation and evaluation of electronic documentation in the court.

Atslēgvārdi: elektroniskais dokuments, elektroniskā saziņa, rakstveida pierādījums

Keywords: electronic document, electronically stored information, written evidence

Mūsdienās privāttiesiskās attiecības nav iedomājamas bez modernāko komunikācijas līdzekḷu izmantošanas savstarpējā subjektu saskarsmē, darījumu slēgšanā, kā arī konfliktsituāciju risināšanā. Tādējādi arvien lielāku nozīmi civiltiesiskajos strīdos iegūst tādu pierādījumu izmantošana, kuri ir ietverti elektroniskā formā un kuru saturs fiksēts noteiktos datu nesējos vai ierīcēs, izmantojot dažādas programmatūras un uzglabājot informāciju un veicot mākoņdatošanu. Tas nozīmē, ka ir nepieciešams izvērtēt pašlaik spēkā esošo regulējumu un, iespējams, veikt atbilstošus grozijumus normativajos aktos, lai nodrošinātu procesuālos instrumentus rakstveida pierādījumu iegūšanai, iesniegšanai un vērtēšanai tiesā civillietās.

Ekonomiskajai aktivitātei paplašinoties ārpus noteiktu valstu robežām, kā arī veicinot brīvā darbaspēka kustību, arvien lielāku nozìmi praksē iegūst tādi civiltiesiskie strīdi, kuros ir iesaistīts ārvalstu elements vai nu pēc subjektu (fizisku vai juridisku personu), vai arī pēc pierādỉjumu atrašanās vietas. Tādējādi nacionālajos civilprocesos ir jāvērtē modernizācijas iespējas, lai tie atbilstu 
civilprocesā noteiktajām prasībām - ātri un pareizi izspriest civiltiesiskos strīdus. Lielā mērā šo problēmu risina starptautiskie normatīvie akti - konvencijas, regulas un starpvalstu sadarbỉbas līgumi.

Jebkura civiltiesiskā strīda izšķiršanai būtiska nozīme ir lietā iegūtajiem pierādijumiem, kuri, ņemot vērā komunikāciju tehnologiju dažādību un elektroniskās saziņas ${ }^{1}$ izmantošanu ikdienā gan publiskajā, gan privātajā jomā, rada nepieciešamību izvērtēt esošā normativā regulējuma pietiekamību, lai nodrošinātu rakstveida pierādījumu iegūšanu un vērtēšanu saistībā ar to elektronisko formu un attiecīgās informācijas uzglabāšanas vietām (ierīcēm).

Pašlaik pierādījumu iegūšanu ārvalstīs civillietās regulē Eiropas Savienības Padomes 2001. gada 28. maija Regula (EK) Nr. 1206/2001 par sadarbïbu starp dalībvalstu tiesām pierādījumu iegūšanā civillietās un komerclietās ${ }^{2}$ (turpmāk arī Regula (EK) Nr. 1206/2001) vai Latvijas Republikai saistošie starptautiskie līgumi, ar kuriem tiek regulēti jautājumi par pierādījumu iegūšanu attiecīgajā valstī. Ārvalsts pierādījumu iegūšanas lūgumu izlemj attiecīgās valsts tiesa, kuras darbības teritorijā atrodas iegūstamā pierādījuma avots, un pieṇem vienu no iespējamajiem lēmumiem, t. i., vai nu par pierādījumu iegūšanas lūguma izpildes piel̦aujamību, pieņemot to izpildei vai nosakot pierādījumu iegūšanas lūguma izpildes iestādi, termiņus un citus nosacỉjumus, vai arī atsakot pieņemt pierādījumu iegūšanas lūgumu vai tā daḷu izpildei. Kā viena no problēmām praksē ir identificējama ilgā un smagnējā procedūra, kurā attiecīgais jautājums tiek izlemts, t. i., Regula (EK) Nr. 1206/2001 10. pantā paredz, ka tiesa, kas saṇem pieprasījumu, izpilda pieprasījumu tūlīt vai, vēlākais, 90 dienās no brīža, kad saņemts pieprasījums. Arī juridiskajā literatūrā tiek atzìts, ka "ārvalsts pierādījumu iegūšanas lūguma izpilde var būt apgrūtināta vai pat neiespējama, ja ārvalsts kompetentā iestāde izsaka lūgumu iegūt pierādījumus ārvalsts procesuālajā kārtībā vai izmantojot tehniskos līdzekḷus". ${ }^{3}$ Ātrums un procesuālā ekonomija civiltiesiskā strīda izskatǐšanā ir kḷuvusi par vienu no vadošajām prasībām mūsdienu tiesvedībā.

Jāatzīst, ka elektronisko pierādījumu iegūšanas ātruma nepieciešamību pašlaik ir apzinājuši krimināltiesību jomas pārstāvji un ES valstis ir uzsākušas darbu pie Elektronisko pierādijjumu regulas izstrādes, kuras mērkis ir izveidot jaunu noteikumu kopumu, lai vienkāršotu elektronisko pierādijumu iegūšanu un apstrādi un iegūtu šos pierādijumus no pakalpojumu sniedzējiem, kas darbojas Eiropas teritorijā. Lai gan darbs pie jaunās regulas izstrādes noris jau vairāk nekā divus gadus, tas ir nozīmīgs solis tai virzienā, lai apzinātos, ka nepieciešams mainīt elektroniskā formā izteikto pierādījumu iegūšanas kārtību, izslēdzot laikietilpīgos starpposmus, kuri nereti aizṇem trīs un vairāk mēnešus. Attiecīgās problēmas pierādījumu iegūšanā pastāv ne tikai kriminālprocesa jomā, bet arī civilprocesuālajā tiesvedībā. Tādējādi arī civilprocesa jomā būtu vēlams uzsākt diskusijas Regulas (EK) Nr. 1206/2001 noteikumu pilnveidošanai vai jauna regulējuma izstrādē, lai radìtu pēc iespējas mazāk administratīvo posmu attiecīgās informācijas pieprasī̌sanai no ārvalstīs esoša elektronisko sakaru pakalpojuma sniedzēja, atrodot līdzsvaru starp tiesvedỉbai nepieciešamo

1 Ar terminu "elektroniskā saziṇa” tiek saprasta elektroniski saglabāta informācija (autores piezīme).

2 Eiropas Savienības Padomes 28.05.2001. Regula (EK) Nr. 1206/2001 par sadarbību starp dalíbvalstu tiesām pierādījumu iegūšanā civillietās un komerclietās. Pieņemta 28.05.2001. [04.12.2008. red.].

3 Civilprocesa likuma komentāri. III daḷa (61.-86. nodaḷa). Sagatavojis autoru kolektīvs prof. K. Torgāna zinātniskajā redakcijā. Rīga: Tiesu namu aǵentūra, 2014, 924. lpp. 
àtrumu pierādījumu iegūšanā un personas datu aizsardzību, kas civiltiesiskā strīdā var būt it īpaši vērtējams jautājums, piemēram, ja civiltiesiskais strīds ir skāris fizisko personu privātās dzīves jautājumus vai arī saimnieciskās darbības veicēja ar komercnoslēpuma aizsardzību saistītās ziṇas. Viennozīmīgi var atzìt, ka tikai tiesnesis kā noteiktas kvalifikācijas amatpersona var izlemt jautājumu par nepieciešamo pieprasāmo datu apjomu, kuriem būtu nozīme attiecīgajā civiltiesiskajā strīdā.

Kà otru problēmu var norādìt to, ka gan minētā regula, gan starpvalstu līgumi pārsvarā regulē pierādijumu iegūšanas lūguma iesniegšanas un izlemšanas jautājumus, bet neregulē noteiktu pierādījumu iegūšanas procedūru. Šis jautājums vienmēr ir katras valsts nacionālo normatīvo aktu kompetence, un, ja pierādījumu iegūšanas lēmums ir pozitīvs, pieprasītais pierādījums tiek iegūts un fiksēts atbilstošā attiecīgās valsts nacionālajā regulējumā noteiktajā kārtībā. Diemžēl arī šajā jautājumā ES valstīs ir sastopama liela dažādība.

Viens no komplicētākajiem jautājumiem pierādījumu iegūšanā ir elektroniskā formā fiksētā saziṇa, tajā skaitā arī audio un video ieraksti. Šie pierādījumi tiek apzīmēti kā elektroniskie jeb e-pierādījumi, kuri, savukārt, civilprocesā tiek pieskaitīti pie rakstveida pierādījumiem. Vairumā Eiropas Savienības dalībvalstu civilprocesa likumos ir ietverts atsevišks regulējums elektroniskajiem pierādījumiem, paredzot galvenokārt elektroniskā formā izteikta dokumenta kā rakstveida pierādījuma definējumu, prasības tā iesniegšanai un vērtēšanai. Piemēram, Vācijas Civilprocesa likuma ${ }^{4}$ 371.a $\$$ regulē elektronisko dokumentu kā pierādījumu, nosakot vērtēšanas kritērijus atkarībā no tā, vai tas ir privāts vai publisks (valsts iestādes sastādīts) elektronisks dokuments vai arī elektroniskās formas ziṇojums, kurš sūtīts no tikai šai personai piešķirtā e-pasta (oficiālā elektroniskā adrese). Tādējādi Vācijā attiecībā uz privātajiem elektroniskajiem dokumentiem darbojas noteikums, ka tā ticamību nodrošina pārbaudāms elektroniskais paraksts, saskaṇā ar Eiropas Parlamenta un Padomes 2014. gada 23. jūlija Regulu (ES) Nr. 910/2014 par elektronisko identifikāciju un uzticamības pakalpojumiem elektronisko darījumu veikšanai iekšējā tirgū un ar ko atcel̦ Direktīvu 1999/93/EK 5 (turpmāk arī Regula (ES) Nr. 910/2014). Lìdzīga prasība ir izvirzìta arī publiskiem elektroniskiem dokumentiem, kuru ticamību apliecina drošs (kvalificēts) elektroniskais paraksts un valsts iestādes izveidota elektroniskā dokumenta noteiktā forma. Savukārt sūtījums no personai piešķirtā e-pasta ir ticams, jo sūtītājs ir pārbaudìts un identificēts. Attiecībā uz citiem elektroniski nosūtītiem dokumentiem Vācijā darbojas noteikums: ja elektroniskais dokuments nav parakstīts, tas, tāpat kā jebkurš cits pārbaudes objekts, ir brīvi jānovērtē, ņemot vērā tā pierādījuma spēku. ${ }^{6}$

Savukārt salīdzinājumam - Igaunijas Civilprocesa likuma ${ }^{7}$ 277. $\$$ noteic, ka elektroniska dokumenta ar elektronisko parakstu autentiskumu var apstrīdēt,

4 Zivilprozessordnung [Vācijas Civilprocesa likums]. Pieejams: https://www.gesetze-im-internet.de/ zpo/_371a.html [aplūkots 20.01.2020.].

5 Eiropas Parlamenta un Padomes 23.07.2014. Regula (ES) Nr. 910/2014 par elektronisko identifikāciju un uzticamības pakalpojumiem elektronisko darījumu veikšanai iekšejjā tirgū un ar ko atceḷ Direktīvu 1999/93/EK. Pieņemta 23.07.2014. [23.07.2014. red.].

6 Thomas Trautwein. Prütting/Gehrlein, ZPO Kommentar, ZPO $\$$ 371a - Beweiskraft elektronischer Dokumente. Pieejams: https://www.haufe.de [aplūkots 20.01.2020.].

7 Code of Civil Procedure (Tsiviilkohtumenetluse seadustik) [Igaunijas Civilprocesa likums]. Pieejams: https://www.riigiteataja.ee/en/eli/513122013001/consolide [aplūkots 20.01.2020.]. 
vienīgi pamatojot apstākḷus, kas dod pamatu uzskatīt, ka dokumentu nav sagatavojis digitālā paraksta turētājs. Iepriekšminētais attiecas arī uz elektroniskiem dokumentiem, kas sagatavoti citā drošā veidā, l̦aujot noteikt personu, kas dokumentu sagatavojusi, un tā sagatavošanas laiku. Tas nozìmēe ka Igaunijas Civilprocesa likums regulē tos jautājumus, kuri vairāk attiecināmi uz procedūru piemērošanu civiltiesiskajā strīdā, bet neregulē tādus jautājumus, kuri vērsti uz elektroniskā dokumenta satura izpratni. Igaunijas Civilprocesa likuma 274. \$ noteic, ka elektronisko dokumentu iesniedz tiesā kā izdruku vai pārsūta elektroniski tādā formātā, ar kuru var iepazìties un kuru droši var glabāt tiesas informācijas sistēmā.

Tādējādi ir redzamas divas pieejas procesa regulējumā: viena, kad nacionālajā civilprocesa regulējumā ir ietverti noteikumi par elektronisko dokumentu kā pierādījumu un tam izvirzìtās prasības (vismaz minimālās), un otra pieeja kad Civilprocesa likums nacionālajā līmenī neizdala atsevišķi elektroniskos pierādījumus no citiem rakstveida pierādījumiem. Otrajā gadījumā jautājums par elektroniskā formā ietvertu pierādỉjumu un tā ticamību ir atstāts citu speciālo likumu regulējumam vai arī attiecīgais gadījums paḳ̦aujas vispārējiem pierādījumu vērtēšanas principiem.

Latvijas Civilprocesa likums ${ }^{8}$ (turpmāk arī CPL) pašlaik vairāk atbilst otrajai pieejai, un attiecībā uz elektroniskā formā izteiktu pierādījumu iesniegšanu un vērtēšanu atsevišķu normu nav. Taču regulējums, kas attiecās uz rakstveida pierādījuma izpratni un iesniegšanu, vairs neatbilst mūsdienu procesa vajadzībām, it īpaši ja Latvijas tiesās ir plānots pāriet no lietām papīra formā uz lietām elektroniskā formā. Tas nozìmē, ka arī Latvijas Civilprocesa likumā ir nepieciešams jauns skatījums uz rakstveida pierādỉjumu iesniegšanu, ietverot atsevišķus noteikumus CPL 111. pantā par elektroniskā formā ietvertu pierādījumu iesniegšanu un vērtēšanu, kas atvieglotu izpratni par elektroniskā formā ietvertas informācijas kā pierādījuma vērtēšanu atbilstoši pierādījumu piel̦aujamības kritērijiem un mazinātu atšķirīgās interpretācijas iespējas tiesu praksē, vērtējot vienādi iegūtas un elektroniskā formā fiksētas ziņas.

Pašlaik informācija par elektroniskā formā sagatavotu dokumentu izpratni, vērtēšanu un ticamību iekl̦auta Elektronisko dokumentu likumā, ${ }^{9}$ kurā ir norādīts, ka "prasība pēc dokumenta rakstveida formas attiecībā uz elektronisko dokumentu ir izpildita, ja elektroniskajam dokumentam ir elektroniskais paraksts un elektroniskais dokuments atbilst citām normatīvajos aktos noteiktajām prasībām". Tādējādi pirmšḳietamajā uztverē vārds "dokuments" liek domāt, ka runa ir par rakstveida informāciju, ko rada jebkurš publisko vai privāto tiesību subjekts, īstenojot iestādes vai amata pilnvaras, vai fiziskā persona, ievērojot obligāti ietveramos rekvizìtus, tajā skaitā parakstu. ${ }^{10}$ Tomēr šāds redzējums ir salīdzinoši šaurs, jo termins “"elektronisks dokuments” ir jebkāds saturs, kas tiek glabāts elektroniskā formātā, jo īpaši teksta vai skaṇas, vizuāls vai audiovizuāls ieraksts". ${ }^{11}$ Šādu definīciju sniedz Regula (ES) Nr. 910/2014, un Latvijas Elektronisko dokumentu likumā tā ir pārṇemta tiešā veidā, ietverot likumā jēdziena “elektroniskais dokuments" skaidrojumu. Tas nozīmē tikai to,

\footnotetext{
${ }^{8}$ Civilprocesa likums: LV likums. Pienemts 14.10.1998. [01.07.2019. red.].

9 Elektronisko dokumentu likums: LV likums. Pieņemts 31.10.2002. [31.12.2019. red.].

10 Dokumentu juridiskā spēka likums: LV likums. Pieṇemts 06.05.2010. [01.01.2017. red.].

11 Regula (ES) Nr. 910/2014.
} 
ka Latvijā attiecībā uz terminu "elektroniskais dokuments" ir vienota izpratne kā Vācijā, Igaunijā vai citā ES valstī, uz kuru attiecas Regulas (ES) Nr. 910/2014 darbība. Tātad šāda pieeja prasa mainīt līdz šim praksē pastāvošo izpratni, ka "dokuments" ir juridiski noformēts rakstveida apliecinājums, ${ }^{12}$ piešķirot līdzvêrtīgu izpratni un pierādỉjuma nozīmi tādām formām kā skaṇas, vizuālais vai audiovizuālais ieraksts.

Regula (ES) Nr. 910/2014 uzsver, ka l̦oti svarīgs ekonomiskās un sociālās izaugsmes faktors ir uzticēšanās tiešsaistes videi. Uzticēšanās trūkums, jo īpaši tad, ja tas rodas šḳietama juridiskās noteiktības trūkuma dēḷ, liek patērētājiem, uzṇēmumiem un publiskām iestādēm vilcināties veikt darỉjumus elektroniski un pieñemt jaunus pakalpojumus. ${ }^{13}$

Elektroniskā formā sastādìti dokumenti tiek ieviesti ikdienā un ieņem arvien lielāku nozīmi, un šādā formā sastādīti dokumenti kḷūst pašsaprotami un pierasti. Taču vienlaikus ar elektroniskā dokumenta êrtu lietošanu un izmantošanu rodas vairāki jautājumi, kas saistās ar to izmantošanu tiesvedībās, pierādišanu un novērtēšanu ne tikai saziņā ar valsts un pašvaldības iestādēm, bet arī privāttiesiskajos darījumos un savstarpējā saziniā.

Praksē vairs nerada šaubas elektroniski parakstīts dokuments ar drošu elektronisko parakstu un laika zīmogu. Tas atbilst tradicionālajai "dokumenta" izpratnei kā atbilstoši noformēts rakstveida apliecinājums un ir kḷuvis pierasts lìdzās papīra formā noformētam dokumentam.

Arī Senāts ir norādījis, ka elektroniskais paraksts nodrošina tikai parakstītāja identifikāciju. ${ }^{14}$ Tādējādi veidojas prezumpcija, ka elektroniskā dokumenta parakstìtājs, ja ir izmantots elektroniskais paraksts, ir zināms un to var identificèt pēc noteiktā elektroniskā paraksta ciparu kombinācijas.

Elektroniski parakstìta dokumenta augstā ticamība izriet no Regulas (ES) Nr. 910/2014, kas 27. pantā noteic, ka elektroniskajam parakstam ir neapšaubāms juridiskais spēks, tas ir pieņemams kā pierādījums tiesvedībā, un to nedrīkst noraidìt tikai elektroniskā formāta dēl vai tādēl, ka tas neatbilst kvalificētu elektronisko parakstu prasībām. Turklāt, kas ir būtiski ņemams vērā, kvalificētu elektronisko parakstu, kura pamatā ir vienā dalībvalstī izsniegts kvalificèts sertifikāts, atzīst par kvalificētu elektronisko parakstu visās citās dalībvalstīs. Tas nozīmè, ka vienīgā iespēja, ja rodas šaubas par elektroniskā dokumenta, kurš parakstīts ar drošu elektronisko parakstu, ticamību, ir strīdēties par to, ka elektronisko parakstu dokumentā ir likusi cita persona, izmantojot attiecīgās personas elektroniskā paraksta radǐšanas datus. Tieši šis jautājums ir noregulēts Igaunijas Civilprocesa likumā un izriet no Vācijas civilprocesa likuma, bet nav noregulēts Latvijas Civilprocesa likumā.

Latvijas Elektronisko dokumentu likumā ir ietverta parakstītāja atbildība, nosakot kā pienākumu nodrošināt, lai elektroniskā paraksta radišanas dati netiktu izmantoti bez parakstītāja ziņas, un gadījumā, ja tomēr tas ir noticis, nekavējoties pieprasìt, lai sertifikācijas pakalpojumu sniedzējs atsauc kvalificētu sertifikātu vai aptur tā darbību. Latvijas tiesai ir nācies saskarties arī ar šāda veida civiltiesiskajiem strīdiem, kad celtajā prasībā viens no vērtējamiem

\footnotetext{
12 Latviešu valodas vārdnīca. Autoru kolektīvs. 2. izd. Rīga: Avots, 2013, 252. lpp.

13 Ibid.

14 Latvijas Republikas Augstākās tiesas Civillietu departamenta 02.02.2016. lēmums Nr. SKC-1406/2016. Pieejams: www.at.gov.lv [aplūkots 22.01.2020.].
} 
jautājumiem bija darījumu spēkā esība, ja elektronisko parakstu ir likusi cita persona, kura nav identificējama ar attiecīgo parakstu. Prasību tiesā cēla persona, kura savu elektronisko parakstu bija uzticējusi citai personai. Lietas izskatî̌anas gaitā tiesa secināja: prasìtāja nav spējusi pierādìt, ka viņas elektroniskais paraksts izmantots prettiesiski, pretēji viņas gribai, un lietā nav arī neviena pierādījuma, kas apliecinātu prasîtājas apgalvoto. Līdz ar to tiesa secināja, ka personas bezatbildīga, likuma nosacijumiem pretēja rīkošanās ar savu elektronisko parakstu nevar būt kā pierādījums pašas personas rīcības radìto seku apstrīdēšanai. ${ }^{15}$ Tādējādi var secināt, ka, izskatot attiecīgos civiltiesiskos strīdus, pat ja Latvijas Civilprocesa likumā nav ietverts regulējums saistībā ar elektroniski parakstītu elektronisko dokumentu vērtēšanu un ticamību, tiesa ievēro speciālajos likumos ietvertos regulējumus un izmanto Civilprocesa likumā ietvertās pierādījumu vērtēšanas prasības, proti - "prasîtājam jāpierāda savu prasījumu pamatotība. Atbildētājam jāpierāda savu iebildumu pamatotība". Tas nozīmè, ka pašlaik nav vērojama izteikta nepieciešamība noteikt Civilprocesa likumā speciālu regulējumu saistîbā ar elektroniskā formā izteiktu pierādỉjumu vērtēšanu, taču šāda nepieciešamība ir attiecibā uz vienotas tiesu prakses radī̌sanu un judikatūru.

Šo apgalvojumu pamato arī citās lietās taisītie tiesas konstatējumi, kuros ir bijis nepieciešams dažāāās situācijās vērtēt elektroniskos dokumentus, piemēram, gadijumā, kad elektroniskajai saziņai bija izmantots personas privātais e-pasts, kura saturs netika parakstìts ar drošu elektronisko parakstu. Praksē var tikt apšaubìta elektroniskā sūtỉjuma ticamība. Tà, piemēram, Zemgales rajona tiesa konstatēja, ka uz tiesas elektroniskā pasta adresi ir saņemta vēstule, kurā persona informē tiesu, ka nevarēs ierasties uz tiesas sēdi, un lūdz to izskatìt bez viṇas klātbūtnes. Vēstule nebija parakstīta ar drošu elektronisko parakstu, un tiesa atzina: tā kā persona nav identificējama, kā to prasa Elektronisko dokumentu likums, tad tiesa nevar atzìt, ka elektroniskā pasta vēstule ir saṇemta no attiecīgās personas. ${ }^{16}$

Pamatojoties uz Civilprocesa likuma 97. panta pirmo daļu, tiesa var apšaubìt pierādijuma ticamību vispār un neṇemt to vērā. Piemēram, kāda sprieduma motīvu daḷā tiesa norādỉja, ka "apgabaltiesa ir vērtējusi elektronisko saraksti, kuru visu kopumā atzinusi par tādiem pierādījumiem, kas nav ticami, jo pieteicējai, ievērojot e-pasta adreses îpatnības, nevarēja rasties pārliecỉba, ka tā sarakstās tieši ar konkrēto Polijas uzñēmumu [..]". ${ }^{17}$ Savukārt citā lietā tiesa atzina, ka "tiesai nav pamata neticēt lietā iesniegtajai Skype sarakstei [..]. Atbildētāja pārstāve tiesas sēdē atzina, ka Skype sarakste starp pusēm ir notikusi [..] Atbildētājs kā pierādījumu nav iesniedzis citu starp pusēm Skype sarakstes variantu, tāpēc tiesai nav pamata uzskatīt, ka prasìtājas iesniegtā Skype sarakste nebūtu ticama. Tiesa šo saraksti vērtē kopsakarā ar citiem rakstveida pierādijumiem lietā". ${ }^{18}$

${ }^{15}$ Vidzemes apgabaltiesas Civillietu tiesas kolēgijas 21.06.2019. spriedums lietā Nr. CA-0077-19/12. Pieejams: www.manas.tiesas.lv [aplūkots 22.01.2020.].

16 Zemgales rajona tiesas 05.11.2019. spriedums lietā Nr. C-4587-19/27. Pieejams: www.manas.tiesas.lv [aplükots 22.01.2020.].

${ }^{17}$ Latvijas Republikas Senāta 05.09.2019. spriedums lietā Nr. A420408113, SKA-785/2019. Pieejams: www.at.gov.lv [aplūkots 22.01.2020.].

${ }^{18}$ Latgales apgabaltiesas 18.04.2017. spriedums lietā Nr. C31388115, CA-0095-17. Pieejams: www.manas. tiesas.lv [aplūkots 22.01.2020.]. 
Lìdz ar to ir pamatots secinājums: ja elektroniskais dokuments nav parakstìts drošā un ticamā veidā, tas, tāpat kā jebkurš cits pārbaudes objekts, ir brīvi jānovērtēe, ņemot vērā tā pierādījuma spēku. Vienotas tiesu prakses veidošana ar elektronisko saziņu saistīto pierādījumu izpratnei un vērtēšanai pašlaik ir atzīstama par vienu no aktuālākajiem jautājumiem, ņemot vērā, ka tiesām ar šādiem pierādījumiem nāksies saskarties arvien biežāk. Tas, savukārt, radīs nepieciešamību ietvert Civilprocesa likumā atbilstošu regulējumu, nostiprinot elektroniskā dokumenta dažādos iegūšanas veidus, noformēšanu un vērtēšanu tiesā.

\section{Secinājumi}

1. Elektronisko pierādījumu iegūšanas ātrums ārvalstīs ir viens no būtiskiem jautājumiem, kura risināšanai ir nepieciešams veikt grozijjumus Regulas (EK) Nr. 1206/2001 saturā, mazinot formālās procedūras, kuru ietvaros jautājuma izlemšana un izpilde ir smagnēja un laikietilpīga. Tādējādi būtu samazināmi pierādījumu pieprasijuma izlemšanas maksimālie termin̨i. Taču vienlaikus ir nepieciešams saglabāt regulējumu, kas paredz attiecīgās valsts tiesneša iesaisti pierādījuma iegūšanas izlemšanā, vērtējot datu aizsardzības jautājumu un iegūstamo datu apjomu.

2. Pašlaik nav vērojama izteikta nepieciešamība noteikt Latvijas Civilprocesa likumā speciālu regulējumu saistībā ar elektroniskā formā izteiktu pierādījumu vērtēšanu, taču ir jāveido vienota tiesu prakse un judikatūra, kas būtu par pamatu, lai izvērtētu nepieciešamību ietvert Civilprocesa likumā atbilstošu regulējumu, nostiprinot elektroniskā dokumenta dažādos iegūšanas veidus, noformēšanu un vērtēšanu tiesā. 